\title{
Application of Digital Image Segmentation of Plantation Fruit Classification in Samarinda Agricultural Polytechnic
}

\author{
${ }^{1}$ Ella Pajriyani \\ Samarinda Polytechnic State \\ Agricultural Engineering Technology \\ Software Agricultural management \\ Samarinda, East Kalimantan \\ ellaelma11@gmail.com
}

\author{
${ }^{2}$ Eny Maria \\ Software Engineering Technology \\ State Agricultural Polytechnic \\ SamarindaAgricultural management \\ Samarinda, East Kalimantan \\ mariaeny.siringo2@gmail.co
}

\author{
${ }^{3}$ Rusmini \\ Software Engineering Technology \\ State Agricultural Polytechnic \\ SamarindaAgricultural management \\ Samarinda, East Kalimantan \\ iefira07@gmail.com
}

\begin{abstract}
Applications of Digital Image Segmentation of Plantation Fruit Agricultural Classification in Samarinda State Polytechnic Based on Form The development of computer technology at this time has brought significant progress in various aspects of human life. Such development is supported by the availability of high Increasingly hardware and software, one of the technologies are experiencing rapid development is image processing. Image processing is a system where the process is Carried out by entering an image and the result is also an image. Currently the use of digital images is Widely used in various fields one of the which is in the plantation sector. Therefore, the purpose of this study is to create a digital image segmentation application for the classification of fruit plantation based on shape.The method used for image segmentation is the thresholding method, while the image classification uses the Artificial Neural Network (ANN) method. The accuracy generated by the system both in the training process and testing shows that the method used can classify images fruit well.
\end{abstract}

Keywords- Image Processing, thresholding, Artificial Neural Networks (ANN), Plantation Fruit

\section{PRELIMINARY}

The development of computer technology today has brought significant progress in various aspects of human life, especially for developing countries. Such developments supported by the availability of hardware and software that is increasingly high. one technology that has developed so rapidly is image processing.Image processing is a system where the process is done with the form of the image and enter the result also in the form of images. At first the image processing is done to improve the quality of the image, but with the development of the computing world characterized by increasing capacity and processing speeds of computers, as well as the emergence of the sciences computing that allows humans to take information from an image, the image processing can not be released by the field of computer vision. The development of information and technology, especially in the computer field has been very fast at all levels of society. With the advance of the human mind today, computers began to be used in all sorts of things in human life. Today the use of digital images is widely used in various fields,

State Agricultural Polytechnic Samarinda especially in the plantation sector has four commodities, namely cocoa, coffee, rubber and pepper.

thresholding is one interesting pattern recognition methods to be used. Thresholding is the process of changing the image of degree of gray into a binary image or black and white so it can know which area including the object and the background of the image clearly with the problems that arise in the process of pattern recognition in the fruit is how an application can recognize the image of the shape of the fruit plantations, of the writer take the title "Application of Digital image Segmentation Classification of fruit plantations in Samarinda Politani Based Forms". This application will make it easier to recognize in particular the introduction of fruit fruit species plantations in Samarinda State Agricultural Polytechnic, which has four commodity crops plantation.

Based on the background of the foregoing, it can be encapsulated formulation of the problem is how to create a digital image segmentation application plantation fruit classification based on the form? Considering the above problems is too broad then, in this study, researchers will limit the issues to be studied. Limitation of problems of this study are as follows:

1. Objects that are used as inputs identification is the image of fruit, especially fruit plantation commodities in Samarinda State Polytechnic Agriculture.

2. The image of the fruit used is a color image (RGB).

3. The image of the fruit to be processed not voting noise or not there is dirt.

4. Fruit image file format used is .jpg, or .png

5. Fruit image taken from a digital camera.

6. Sampling of image data using a plain background.

7. Image recognition using thresholding method.

8. Fruit image classification using Artificial Neural Network (ANN).

9. Using Matlab application 2017a.

The purpose of research and the results expected from the formulation of the above is to create a digital image segmentation application plantation fruit classification based on the form, and the expected result is the app can identify the fruit properly.

\section{LITERATURE REVIEW}

\section{A. Scientific studies}

Some of the literature is used as a guide and reference in this final project, among others:

1. Research conducted by Aditya (2014) under the title Fruit Recognition System Using Discrete Cosine Transform method and Euclidean This system aims to make software that can be used to identify an object the object is to use fruits with different sizes and shapes.

2. The study was conducted by Arinda et al (2017) with the title of Digital Image Segmentation Form Leaves On Plants In Samarinda Politani Method Using thresholding. This system aims to compare the types 
of bone shape of leaves, using a Matlab application in 2008.

3. The study was conducted by Kumaseh et al (2013) with the title of Image Segmentation Digital Fish Method Using thresholding this system aims to recognize the genius-type of fish based on their characteristics and segmentation and characterized by a process of edge detection using the operator Canny sharpened by the dilation, the study using Matlab R2012a application.

4. The study was conducted by Prihartini et al (2015) with the title of Edge Detection Methods Laplacian Of Gaussian On Imagery Leaves Coffee Plant. This system aims to detect the coffee leaves are exposed to diseases and pests, One disease that attacks coffee plants are leaf spot. Edge detection on the leaves of coffee is one of the early forms of the disease management. Edge detection on the leaves of coffee plants conducted to identify geometric leaf area using Matlab application.

5. The study was conducted by Pahlavi (2018)with Image Processing Applications title leaves Method Using Artificial Neural Network (ANN). This system aims to detect mango leaves, lime leaves, cocoa leaves, and the leaves of papaya using Artificial Neural Network (ANN) using MATLAB 2013a.

While at Digital Image Segmentation Application Form Fruit plantations in Samarinda Politani Method Using thresholding segmentation and Method of Artificial Neural Network (ANN) for classification of fruit using Matlab 2017a.

\section{B. Theoretical basis}

1. image segmentation

Image segmentation is the image processing aimed at separating region (region) object with the background region so that the object is analyzed in order to recognize objects that involve a lot of visual perception, in general, the output of the segmentation process is in the form of a binary image in which the foreground logic 1 while the background logic 0 .

2. thresholding

In general, thresholding on grayscale images intended to generate a binary image, mathematically be written as follows.

$$
g(x, y)\left\{\begin{array}{l}
1 \text { if } f(x, y)>T \\
0 \text { if } f(x, y) \leq T
\end{array}\right\}
$$

With $\mathrm{g}(\mathrm{x}, \mathrm{y})$ is a binary image of a grayscale image $\mathrm{f}(\mathrm{x}, \mathrm{y})$, and $\mathrm{T}$ states the threshold value.

3. grayscale

To make changes to an image in full color (RGB) into a grayscale image (gray image), a commonly used method, namely:

Where:

$$
(\mathrm{R}+\mathrm{G}+\mathrm{B}) / 3
$$

R: Elements red

$\mathrm{G}$ : Elements of green

B: Elements blue
The resulting value of the above equation to be inputted to each element of the base color grayscale image.

4. RGB image

An image of the RGB (Red, Green, Blue) consists of three areas of the image are independent of each other, each made up of primary colors, namely red, green and blue in each pixel. Each color component using 8 bits (values range from 0 to 255). Thus, the possibility of color that can be presented achieve $255 \times 255 \times 255$ or $16,581,375$ colors.

\section{Draft Method of Application}

\section{Artificial Neural Network (ANN)}

Artificial neural network (ANN) is one of the artificial representation of the human brain is always trying to simulate the learning process of the human brain. The term is used here because the artificial neural network is implemented using a computer program that is able to resolve a number of the calculation process during the learning process.

JST is determined by three things:

a. The pattern of relationships between neurons (called a network architecture)

b. The method for determining the weights link

c. Activation function as an example, consider the neuron Y in Figure 1.

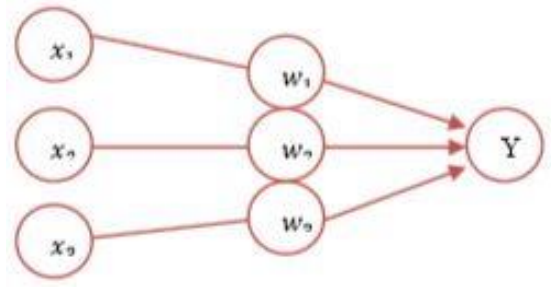

Picture 1 function Activation

$\mathrm{Y}$ receives input from the neuron with the weight of each relationship. $X_{1}, X_{2}, X_{3} W_{1}, W_{2}, W_{3}$

Third impulse neurons that summed as follows:

net $=. X_{1} W_{1}+X_{2} W_{2}+X_{3} W_{3}$

The amount of impulses received by $\mathrm{Y}$ following the activation function $\mathrm{y}=\mathrm{f}$ (net).

2. Basic Concepts of Neural Networks

Each of the patterns of input and output information that is given into ANN processed in neurons. Neurons are collected in layers called neurons layers. The layers making up the neural network can be divided into three, namely:

a. The input layer, the units in the input layer are called units of input. The input unit receives data from outside pattern that describes the problem.

b. Hidden layer, the units in the hidden layer called the hidden units. Where output can not be directly observed.

c. Output layer, the units in the output layer are called units of output. The output of this layer is a neural network solution to a problem.

3. Architecture Artificial Neural Network (ANN) ANN has some network architectures are commonly used in various applications. The ANN architecture, among others (Herman, 2006):

a. Single Layer Networks (Single Layer Network) 
b. Many network layer (Multilayer Net)

c. Competitive Layer Networks (Competitive Layer)

4. Activation Function Backpropagation In backpropagation, the activation function used must meet several requirements, namely: continuous, terdiferensial easily and is a function that does not go down. One function that satisfies the three conditions that often used is a binary sigmoid function which has the range $(0,1)$. The graph is given by the derivative function is shown in Figure 2. $f(x)=$

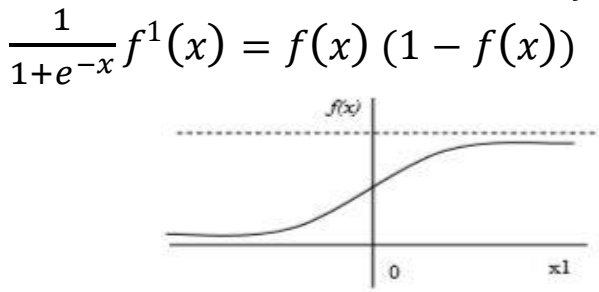

Picture 2 Sigmoid Activation Functions Binary

Another function that is often used is a bipolar sigmoid function whose function is similar to the form of binary sigmoid function, but with the range $(-1,1)$.

Rendered with derivatives. $f(x)=\frac{2}{1+e^{-x}}-$

$$
2 f^{1}(x)=\frac{(1+f(x))(1-f(x))}{2}
$$

Graph the function shown in Figure 3.

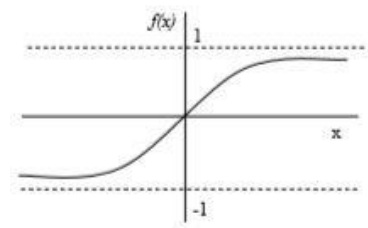

Picture 3 Bipolar Sigmoid Activation Functions

The sigmoid function has a maximum value $=1$. Then for patterns that target more than one, the pattern of inputs and outputs must first be transformed so that all patterns have the same range as the sigmoid function is used. Another alternative is using sigmoid activation function not only on the layer output layer. In the output layer, the activation function used is the identity function: $\mathrm{f}(\mathrm{x})=\mathrm{x}$..

5. Training Standard Backpropagation

Backpropagation training includes 3 Stage: stage forward, backward propagation, and changes in weight. Training algorithm to network with one hidden layer (with a binary sigmoid activation function) is as follows:

Step 0: Initialize all weights to small random numbers

Step 1: If the termination condition is not met, do steps 2-8

Step 2: For each pair of training data, perform steps 3-8

\section{Phase I: Propagation Forward}

Step 3: Each of the input unit receives the signal and forward it to the hidden units on it
Step 4: Calculate all output in the hidden units $Z_{j}(j=$ $1,2, \ldots, p)$

$$
\begin{gathered}
Z_{-} \text {net }_{j}=v_{j o}+\sum_{i=1}^{n} x_{i} v_{j i} \\
Z_{j}=f\left(z_{n e t_{j}}\right)=\frac{1}{1+e^{-z_{-} n e t_{j}}}
\end{gathered}
$$

Step 5: Calculate all the output network $y_{k}(k=$

$$
\begin{gathered}
1,2, \ldots, m) \\
y_{-} \text {net }_{k}=w_{k o}+\sum_{j=1}^{p} z_{j} w_{k j} \\
y_{k}=f\left(y_{- \text {net }_{k}}\right)=\frac{1}{1+e^{-y_{-} \text {net }_{k}}}
\end{gathered}
$$

Phase II: Propagation retreat

Step 6: Calculate the output unit based on the error factor in each unit of output

$$
\begin{gathered}
y_{k}(k=1,2, \ldots, m) \\
\delta_{k}=\left(t_{k}-y_{k}\right) f^{\prime}\left(y_{-} n e t_{k}\right) \\
=\left(t_{k}-y_{k}\right) y_{k}\left(1-y_{k}\right)
\end{gathered}
$$

$\delta_{k}$ an error unit to be used in the layer beneath the weight change (step 7)

Calculate the weight change rate (which will be used later to change weight) at a rate of acceleration $\alpha . W_{k j} w_{k j}$

$$
\begin{gathered}
\Delta w_{k j}=\alpha \delta_{k} z_{j} \quad ; k=1,2, \ldots, m \quad ; j \\
=0,1,2, \ldots, p
\end{gathered}
$$

Step 7: Calculate the hidden units based on the error factor in each hidden unit

$$
\begin{aligned}
z_{j}(j=1,2, \ldots, p) \\
\delta \_n e t_{j}=\sum_{k=1}^{m} \delta_{j} w_{k j}
\end{aligned}
$$

Factors hidden units: $\delta$

$$
\delta_{j}=\delta_{-} n e t_{j} f^{\prime}\left(\delta \_n e t_{j}\right)=\delta_{-} \text {net }_{j} z_{j}\left(1-z_{j}\right)
$$

Calculate the weight change rate (which will be used later for changing the weights) $v_{j i} v_{j i}$

$$
\begin{aligned}
\Delta v_{j i}=\alpha \delta_{j} x_{i} & ; j \\
& =1,2, \ldots, p \\
& =0,1,2, \ldots, n
\end{aligned} ; i
$$

Phase III: Changes in weight

Step 8: Calculate all the weight change in weight change line leading to the unit output: 


$$
\begin{aligned}
w_{k j}(\text { baru })= & w_{k j}(\operatorname{lama}) \\
& +\Delta w_{k j}(k \\
& =1,2, \ldots, m) ; j \\
& =0,1,2, \ldots, p
\end{aligned}
$$

Weight change lines leading to the hidden units:

$$
\begin{aligned}
v_{j i}(\text { baru })= & v_{j i}(\text { lama }) \\
& +\Delta v_{j i}(j=1,2, \ldots, p) ; i \\
& =0,1,2, \ldots, n
\end{aligned}
$$

After the training is completed, the network can be used for pattern recognition. In this case, only the forward propagation (steps 4 and 5) are used to determine the network output. If the activation function is used instead of the binary sigmoid, then steps 4 and 5 should diselesaikan.Demikian also derivatives in steps 6 and 7 .

Step 9: Test the stop condition (end of iteration).

\section{RESEARCH METHODS}

\section{Research procedure}

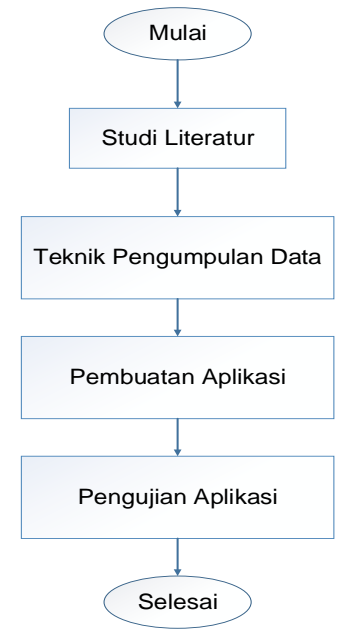

Picture 4 Research Procedure Diagram

II. Draft Flow System

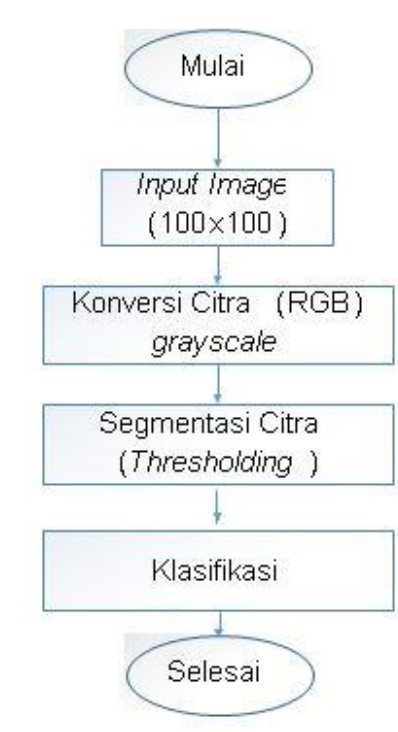

Picture 5 System Design Flow Diagram
C. Calculation of Artificial Neural Networks

$\mathrm{X} \quad$ : Vector input learning.

$\mathrm{X}=(\mathrm{x} 1, \mathrm{x} 2, \ldots ., \mathrm{xj}, \ldots ., \mathrm{xn})$.

$\mathrm{T} \quad$ : Vector target output. $\mathrm{T}=(\mathrm{t} 1, \mathrm{t} 2, \ldots ., \mathrm{tk}, \ldots ., \mathrm{tm})$.

$\Delta \mathrm{k} \quad$ : The error correction weight adjustment wjk based on the error output neurons yk..

dj $\quad$ : The error correction weight adjustment VIJ based on the error output neurons ZJ.

$\alpha \quad$ : Learning rate.

$\theta \quad$ : Tolerance error.

$\mathrm{xi} \quad$ : Input neurons.

Voj : Bias at Hidden neurons to-j.

zi : Hidden neuron $\mathrm{j}$.

Wok : Bias in the k-th output neuron.

Yk : Output neuron-k.

The output value by using the activation function Selected shown with yk:

$\mathrm{Yk}=\mathrm{f}\left(\mathrm{y} \_\right.$in $)$

At initialization set:

$\mathrm{X}=00 \mathrm{Y}=0$

011

101

110

The number of neurons in the input layer $=2$

The number of neurons in the hidden layer $=4$

The number of neurons in the output layer $=1$

Learning rate $(\alpha) \quad=1$

maximum epoch $\quad=1000$

Target error $\quad=0.01$

The initial weight

a. The initial weight input to hidden $\mathrm{V}=0.767079935 \quad 0.660994662$

$0.891735494 \quad 0.993939753$

$0.993006887 \quad 0.321536811$

$0.896309641 \quad 0.988632252$ 
b. The initial weight bias to hidden Vo $=0.892077869 \quad 0.425813755$ $0.894132205 \quad 0.993944954$

c. Early Bobor hidden to output $\mathrm{W}=0.892073581$

0.42591887

0.894103998

0.993939915

d. The initial weight bias to the output $\mathrm{Wo}=0.901970749$

epoch number 1

Operations on the hidden layer / outputs of the hidden units

weighted Pengundahan

$$
\begin{aligned}
\mathrm{z}_{\text {net }} 1= & \mathrm{V} \text { oll }+\mathrm{VII} * \mathrm{VII}+\mathrm{V} 21 * \mathrm{X} 12 \\
= & 0.892077869+(0.767079935 \times 0) \\
& +(0.993006886 \times 0) \\
= & 0.892077869 \\
\mathrm{z}_{\text {net }} 2= & \mathrm{V} \text { oll }+\mathrm{V} 12 * \mathrm{~V} 22 * \mathrm{X} 11+\mathrm{X} 12 \\
= & 0.425813755+(0.660994662 \times 0) \\
+ & (0.32136811 \times 0) \\
= & 0.425813755 \\
\mathrm{Z}_{\text {net }} 3= & \mathrm{V} 03+\mathrm{V} 13 * \mathrm{~V} 23 * \mathrm{X} 11+\mathrm{X} 12 \\
= & 0.894132205+(0.891735494 \times 0) \\
& +(0.896309641 \times 0) \\
= & 0.894132205 \\
\mathrm{Z}_{-} \text {net } 4= & \mathrm{V} 04+\mathrm{V} 14 * \mathrm{~V} 14 * \mathrm{X} 11+\mathrm{X} 12 \\
= & 0.993944554+(0.993939753 \times 0) \\
& +(0.98863225 \times 0) \\
= & 0.993944554
\end{aligned}
$$

Activation

$$
\begin{array}{r}
\mathrm{z}_{1}==\frac{1}{1+e(-0,892077869)} \frac{1}{1+0,4098033498} \\
=0.7093187856
\end{array}
$$

Operations in the output layer / output network unit

1. Multiplication

$$
\begin{aligned}
& \gamma \text { net } \mathrm{I}=\mathrm{Wo}+\mathrm{W} 1+\mathrm{W} 2 \times \mathrm{x} \text { × z1 z2 }+\mathrm{W} 3 \times \mathrm{z} 3+ \\
& \mathrm{W} 4 \text { x z4 } \\
& =0,901979749+(0.892073581) \mathrm{x} \\
& 0.7093187856)+(0.42591887 x \\
& 0.60487359)+(0.894103998 x \\
& 0.709742178)+(0.993939915 x \\
& 0.7298663384) \\
& =0.901970749+0.6327645491+ \\
& 0.2576270759+0.6345833189+ \\
& =3.15238898 \\
& 0.6583180879
\end{aligned}
$$

2. Activation

$$
\begin{aligned}
& \gamma k==\frac{1}{1+e(-3,082637808)} \frac{1}{1+0,0457179728} \\
& =0.9562807813 \\
& \text { Error }=0 \text { to } 0.9562807813
\end{aligned}
$$

Total error squared error $=(-0.9562807813)$

$$
=-0.9562807813
$$

$$
\begin{aligned}
& \delta=(\mathrm{Tk}-\mathrm{yk})(\mathrm{yk})(1-\mathrm{yk}) \\
& =(0.9562807813)(0.9562807813) \\
& \quad(1-0,9562807913 \\
& =(-0.9562807813)(0.9562807813) \\
& \quad(0.0437192187) \\
& =-0.0399800421 \\
& \Delta \mathrm{W} 1=\mathrm{L} * \delta * \mathrm{z} 1 \\
& =\mathrm{L} *(-0.0399800421) * 0.7093187856 \\
& =-0.0283585949 \\
& \Delta \mathrm{W} 2=\mathrm{L} * \delta * \mathrm{z} 2 \\
& =\mathrm{L} *(-0.0399800421) * 0.60487359 \\
& =-0.0241828716 \\
& \Delta \mathrm{W} 3=\mathrm{L} * \delta * \mathrm{z} 3 \\
& =\mathrm{L} *(-0.0399800421) * 0.709742178 \\
& =-0.0283755222 \\
& \Delta \mathrm{W} 4=\mathrm{L} * \delta * \mathrm{z} 4 \\
& =\mathrm{L} *(-0.0399800422) * 0.7298663384 \\
& =-0.0291800869
\end{aligned}
$$

Factors hidden units based on each unit of error hidden

$$
\begin{aligned}
& \delta \text { net } 1=\delta \times \mathrm{W} 1 \\
& =-\mathrm{X} 0.03998004210 .892073581 \\
& =-0.0356651393 \\
& \delta \_ \text {net } 2=\delta \times \mathrm{W} 2 \\
& =-0.0399800421 \times 0.42591887 \\
& =-0.0170282544 \\
& \delta \_ \text {net } 3=\delta \times \mathrm{W} 3 \\
& =-\mathrm{X} 0.03998004210 .894103988 \\
& =-0.0357463155 \\
& \delta \text { net } 4=\delta \times \mathrm{W} 4 \\
& =-\mathrm{X} 0.03998004210 .993939915 \\
& =-0.0397377596 \\
& \delta 1=\Delta \text { net } 1 \mathrm{X} \mathrm{z} 1(1-\mathrm{z} 1) \\
& =-\overline{0} .0346651393 * 0.7093187856 \\
& \text { (1 to } 0.7093187856 \text { ) } \\
& =-0.0073536398 \\
& \delta 2=\delta \_ \text {net } 2 \text { X z2 }(1-\mathrm{z} 2) \\
& =-0.0357463155 * 0.709742178 \\
& \text { (1 to } 0.60487359 \text { ) } \\
& =-0.0040697789 \\
& \delta 3=3 \text { X z3 } \delta \_ \text {net }(1-z 3) \\
& =-0.035746 \overline{3} 155 * 0.709742178 \\
& \text { (1-0.709742178) } \\
& =-0.007834755 \\
& \delta 4=\delta \_ \text {net } 4 \text { X z4 }(1-\mathrm{z} 4) \\
& =-0.0397377596 * 0.7298663384 \\
& \text { (1 to } 0.7298663384 \text { ) } \\
& =-0.007834755
\end{aligned}
$$

Spare change in weight

$\Delta \mathrm{V} 11=$ L. $\delta 1 . \mathrm{X} 11$

As well.

$$
=\mathrm{L} *(-0.0073536398) * 0=0
$$

$$
\begin{aligned}
& \begin{array}{l}
\Delta \mathrm{V} 12=\Delta \mathrm{V} 13=\Delta \mathrm{V} 14=\Delta \mathrm{V} 21=\Delta \mathrm{V} 12 \\
=\Delta \mathrm{V} 23=\Delta \mathrm{V} 24=0 \\
\mathrm{~V} 11(\text { new })=\mathrm{V} 11(\text { old })+\Delta \mathrm{V} 11 \\
=0.767079935+0=0.767079935 \\
\mathrm{~V} 12(\text { new })=\mathrm{V} 12(\text { old })+\Delta \mathrm{V} 12 \\
=0.660994662+0=0,660994662 \\
\mathrm{~V} 13(\text { new })=\mathrm{V} 13(\text { old })+\Delta \mathrm{V} 13 \\
=0.891735494+0=0,891735494
\end{array}
\end{aligned}
$$




$$
\begin{aligned}
& \mathrm{V} 14(\text { new })=\mathrm{V} 14(\text { old })+\Delta \mathrm{V} 14 \\
& =0.993939753+0=0,993939753 \\
& \mathrm{~V} 21(\text { new })=\mathrm{V} 21 \text { (old) }+\Delta \mathrm{V} 21 \\
& =0.993006887+0=0,993006887 \\
& \mathrm{~V} 22(\text { new })=\mathrm{V} 22(\text { old })+\Delta \mathrm{V} 22 \\
& =0.321536811+0=0,321536811 \\
& \mathrm{~V} 23(\text { new })=\mathrm{V} 23(\text { old })+\Delta \mathrm{V} 23 \\
& =0.896309641+0=0,896309641 \\
& \mathrm{~V} 24(\text { new })=\mathrm{V} 24(\text { old })+\Delta \mathrm{V} 24 \\
& =0.988632252+0=0,988632252
\end{aligned}
$$

Changes to the weight of the line output unit

$\mathrm{W} 1($ new $)=\mathrm{W} 1$ (old) $+\Delta \mathrm{W} 1$

$$
\begin{aligned}
& =0.892073581+(-0.0283585949) \\
& =0.8637149861 \\
& \mathrm{~W} 2(\text { new })=\mathrm{W} 2(\text { old })+\Delta \mathrm{W} 2 \\
& =0.42591887+(-0.0241828716) \\
& =0.4017359984 \\
& \mathrm{~W} 3(\text { new })=\mathrm{W} 3(\text { old })+\Delta \mathrm{W} 3 \\
& =0.894103998+(-0.0283755222) \\
& =0.8637284758 \\
& \mathrm{~W} 4(\text { new })=\mathrm{W} 4(\text { old })+\Delta \mathrm{W} 4 \\
& =0.993939915+(-0.0291800869) \\
& =0.9647598281
\end{aligned}
$$

In the second data, also carried out operations using the same weights of the end results of this first data processing as the weight initially. This process is repeated until the maximum epoch (1000) or squared error < target error (0.01).

\section{RESULTS AND DISCUSSION}

A. result

1. Implementation Interface is a display of the application. Here are some of the interfaces contained in the application:

a. The initial view (home)

The initial view (home) show the title of the application and there are several menus among which the home menu, grayscale images. Edge detection, classification process, about, and exit. The home screen can be seen in Figure 6 .

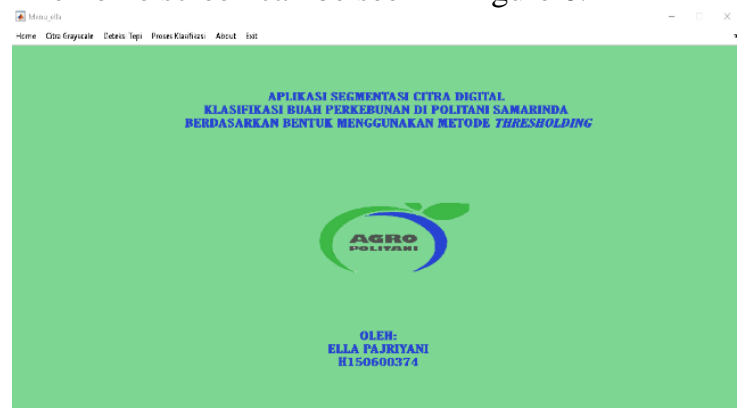

Picture 6 Home (Home)

b. Display grayscale image conversion.

Display grayscale image conversion is a page that converts the original image into a gray image is then converted into a binary number (thresholding). The conversion display grayscale images can be seen in Figure 7 and Figure 8.

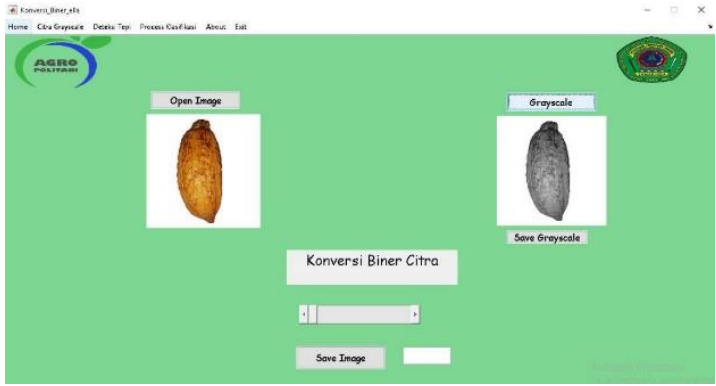

Picture 7 Convert Image Grayscale Display

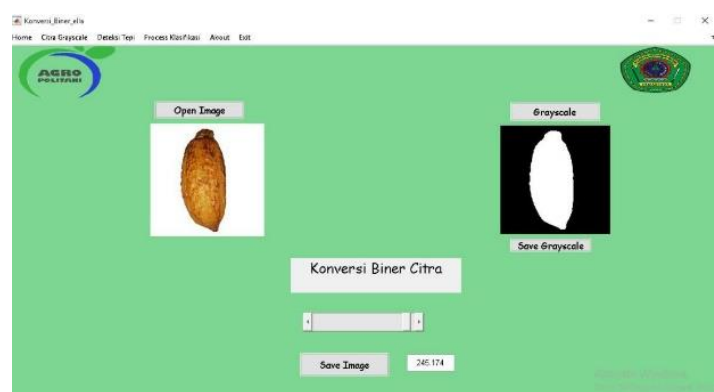

Picture 8 Binary Image Conversion display Fruit (thresholding)

c. Views edge detection comparison

In view of edge detection comparison image are open pushbutton and PopupMenu (menu selection) you want to display edge detection, edge detection as for the comparison view can be seen in Figure 9.

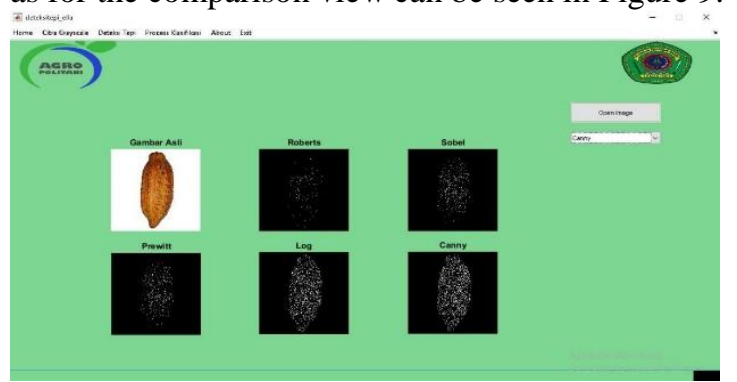

Picture 9 Image Edge Detection Comparison view Fruit

d. Display image classification process

Display image classification process is the identification page or image classification of fruit plantations such as cacao, rubber, coffee and pepper using Artificial Neural Network (ANN). The classification results to see some fruits of the foregoing can be seen in Figure 10, Figure 11, Figure 12 and Figure 13.

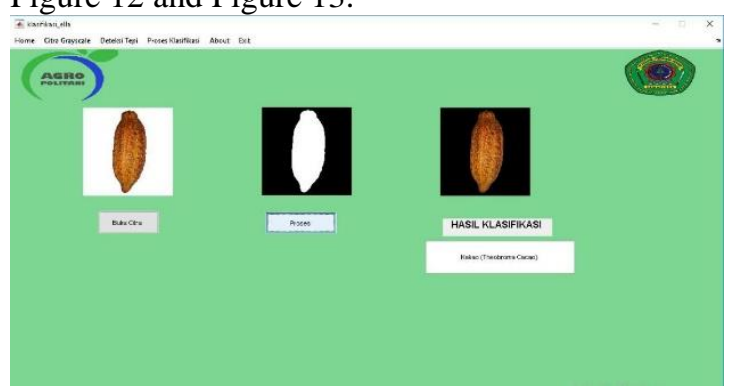

Picture 10 Display Image Classification Process Cocoa Fruit 


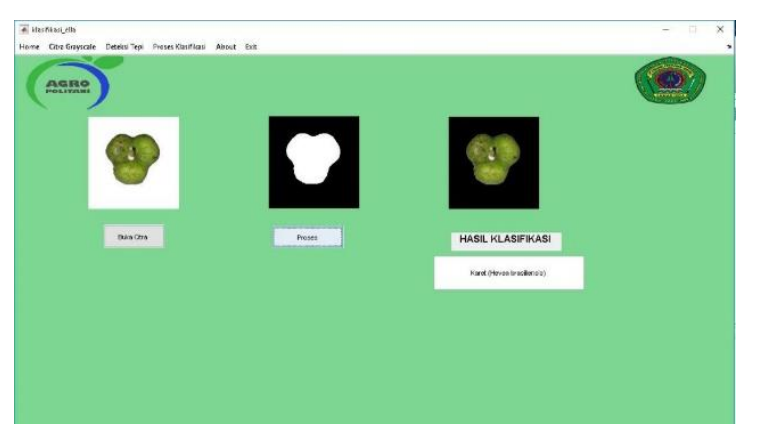

Picture 11 Image Classification Process Display Fruit Rubber

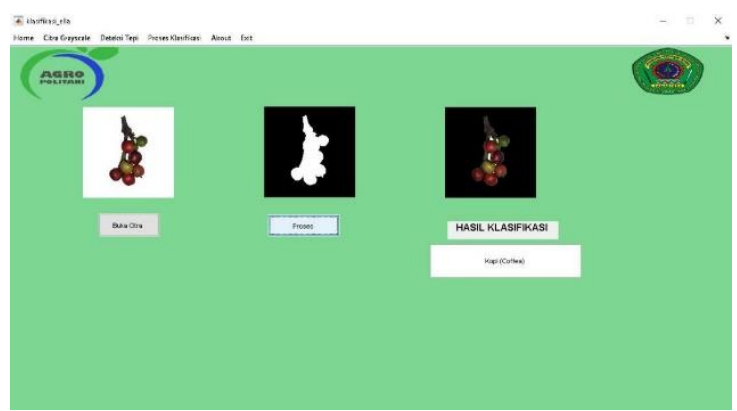

Picture 12 Image Classification Process Display Coffee Fruit

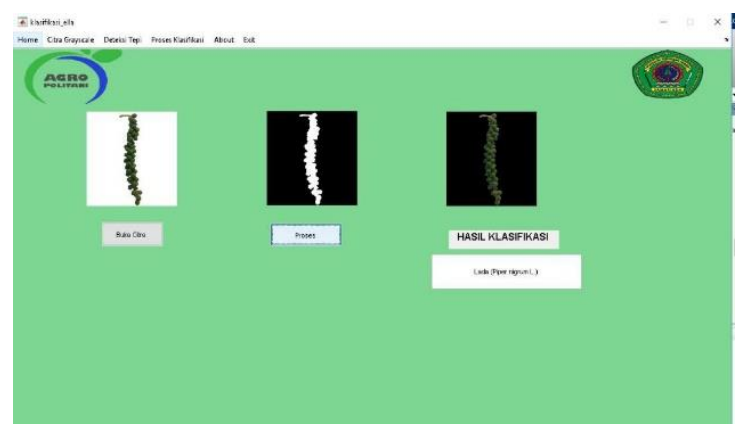

Picture 13 Image Classification Process display Pepper Fruit

e. Views about (about)

Views about (about) contains information about the manufacturer of the application. The views about (about) can be seen in Figure 14.

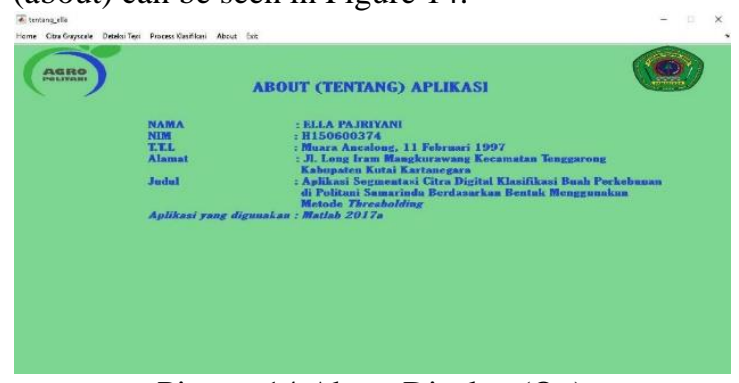

Picture 14 About Display (On)

2. implementation and Application

Classification of programming steps are started from:

a. Prepare training images and test images.

b. Conduct training network with the stages as follows:

1) Image reading practice $80 \%$.

2) Thresholding image segmentation method on the red channel
3) Morphological operations to improve segmentation results

4) Extraction of the form based on parameters of metric and eccentricity

5) Setting a target practice, namely class Cocoa (Theobroma cacao) is symbolized by the numbers 1, class Rubber (Hevea brasiliensis) with number 2 , class Coffee (Coffea) with the number 3, and grade pepper (Piper nigrum L.) with the number 4 .

6) Architecture build back propagation neural network.

7) Train network with feature extraction results as input.

8) Calculate the accuracy of the test results.

\section{B. Discussion}

1. Testing System

Testing of the system or systems analysis in this study using black box method. Testing is done by running all the functions one by one that already exists. Then see whether the result of the function has been as expected. The results of the testing of the application can be seen in Table 1.

Table 1 Application Testing Results

\begin{tabular}{|c|c|c|c|c|}
\hline No & Skenario Pengujian & $\begin{array}{c}\text { Prosedur yang } \\
\text { dijalankan }\end{array}$ & $\begin{array}{l}\text { Hasil yang } \\
\text { diharapkan }\end{array}$ & Keterangan \\
\hline 1 & Menjalankan aplikasi & $\begin{array}{c}\text { User } \\
\text { menekanimemilih } \\
\text { main menu } \\
\text { (menu utana) }\end{array}$ & $\begin{array}{c}\text { Halaman aplikasi } \\
\text { terbuka sesuai } \\
\text { dengan yang dipilih } \\
\text { user }\end{array}$ & Berhasil \\
\hline 2 & Menu grayscale & $\begin{array}{c}\text { User } \\
\text { menekanimemilih } \\
\text { button Open image, } \\
\text { Grascaie, } \\
\text { Thereshoiding, dan } \\
\text { Save image }\end{array}$ & $\begin{array}{c}\text { Menampilkan } \\
\text { gambar asli, } \\
\text { grayscale, } \\
\text { thresholding, dan } \\
\text { menyimpan gambar } \\
\text { ke folderyang } \\
\text { diinginkan }\end{array}$ & Berhasil \\
\hline 3 & Menu deteksi tepi & $\begin{array}{c}\text { User } \\
\text { menekanimemilih } \\
\text { button Open image } \\
\text { dan Listbox }\end{array}$ & $\begin{array}{c}\text { Menampilkan } \\
\text { gambar asli dan } \\
\text { menampilkan hasil } \\
\text { deteksi tepi } \\
\text { Roberts, Sobel, } \\
\text { Prewitt, Log, dan } \\
\text { Canny }\end{array}$ & Berhasil \\
\hline 4 & Menu klasifikasi & $\begin{array}{c}\text { User } \\
\text { menekanimemilih } \\
\text { button Open image } \\
\text { dan button Proses }\end{array}$ & $\begin{array}{c}\text { Menampilkan } \\
\text { gambar asli dan } \\
\text { gambar } \\
\text { threshoiding (hitam } \\
\text { putih) kemudian } \\
\text { menampilkan hasil } \\
\text { identifikasi pada } \\
\text { Textbox }\end{array}$ & Berhasil \\
\hline
\end{tabular}

2. Testing Data (Data Accuracy Applications)

Testing data on classification application on fruit plantations image databases will be conducted to determine how the level of accuracy in the application. The results of the test image classification performed pieces of data can be seen in Table 2 . 
Table 2 Results of classification or grouping Process test of Data On applications.

\begin{tabular}{|c|c|c|c|}
\hline \multirow{2}{*}{ No } & \multicolumn{2}{|c|}{ Kelas } & \multirow{2}{*}{ Keterangan } \\
\hline & Aबा & Aplikasi & \\
\hline 1 & 1 & 1 & Benar \\
\hline 2 & 1 & 1 & Benar \\
\hline 3 & 1 & 1 & Benar \\
\hline 4 & 1 & 1 & Benar \\
\hline 5 & 1 & 1 & Benar \\
\hline 6 & 1 & 1 & Benar \\
\hline 7 & 1 & 1 & Benar \\
\hline 8 & 1 & 1 & Benar \\
\hline 9 & 1 & 1 & Benar \\
\hline 10 & 1 & 1 & Benar \\
\hline 11 & 2 & 2 & Benar \\
\hline 12 & 2 & 2 & Benar \\
\hline 13 & 2 & 2 & Benar \\
\hline 14 & 2 & 2 & Benar \\
\hline 15 & 2 & 2 & Benar \\
\hline 16 & 2 & 2 & Benar \\
\hline 17 & 2 & 2 & Benar \\
\hline 18 & 2 & 2 & Benar \\
\hline 19 & 2 & 2 & Benar \\
\hline 20 & 2 & 2 & Benar \\
\hline 21 & 3 & 3 & Benar \\
\hline 22 & 3 & 3 & Benar \\
\hline 23 & 3 & 3 & Benar \\
\hline 24 & 3 & 3 & Benar \\
\hline 25 & 3 & 3 & Benar \\
\hline 26 & 3 & 3 & Benar \\
\hline 27 & 3 & 3 & Benar \\
\hline 28 & 3 & 3 & Benar \\
\hline 29 & 3 & 3 & Benar \\
\hline 30 & 3 & 3 & Benar \\
\hline 31 & 4 & 4 & Benar \\
\hline 32 & 4 & 4 & Benar \\
\hline 33 & 4 & 4 & Benar \\
\hline 34 & 4 & 4 & Benar \\
\hline 35 & 4 & 4 & Benar \\
\hline 36 & 4 & 4 & Benar \\
\hline 37 & 4 & 4 & Benar \\
\hline 38 & 4 & 4 & Benar \\
\hline 39 & 4 & 4 & Benar \\
\hline 40 & 4 & 4 & Benar \\
\hline
\end{tabular}

In Table 2 there are 40 pieces of image data in the test correctly so that the accuracy of the resulting image data in the testing process the test piece is equal to $40 / 40 * 100 \%=100 \%$. The resulting accuracy of applications both in the process of training and testing indicated that the method used to classify images with good fruit.

3. Total Data Owned

Total data owned amounted to 200 (two hundred) of data pieces and each piece has a 50 (fifty) and each fruit has 20 (twenty) fruit characters ranging from the young to the mature fruit. Data owned fruit of which is cocoa, rubber, coffee and pepper.

4. Total Data Test

Total owned test data are 40 data from each image of the pieces of data that have been taken and imported into a folder on the laptop.

5. Total training data

Total training data owned amounted to 160 data from each of the pieces of data images that have been taken and imported into a folder on the laptop, which is useful for the detection process of data classification.

6. Presentation calculation accuracy

Testing accuracy presentation is very important because it can determine how much the level of accuracy in the application. Accuracy of calculation formula can be seen as follows:

$$
\text { Akurasi }=\frac{\text { jumlah data benar }}{\text { jumlah data } \text { uji }} \times 100
$$

7. test of respondents
Table 3 Results Penguian respoden

\begin{tabular}{|c|c|c|c|c|c|c|c|}
\hline \multirow{3}{*}{ No } & \multirow{3}{*}{ Pertanyaan } & \multicolumn{5}{|c|}{ Nilai } & \multirow{3}{*}{$\begin{array}{l}\text { Jumlah } \\
\text { responden }\end{array}$} \\
\hline & & & & & & & \\
\hline & & 88 & $\mathrm{~s}$ & C & KS & TS & \\
\hline 1 & $\begin{array}{l}\text { Apakah Aplikasi ini mudah } \\
\text { dijalankan? }\end{array}$ & $\begin{array}{c}(9) \\
27,27 \\
\%\end{array}$ & $\begin{array}{l}(24) \\
72,7 \%\end{array}$ & $\begin{array}{l}(0) \\
0 \%\end{array}$ & $\begin{array}{l}(0) \\
0 \%\end{array}$ & $\begin{array}{l}(0) \\
0 \%\end{array}$ & \\
\hline 2 & $\begin{array}{l}\text { Apakah Aplikasi Segmentasi } \\
\text { Citra Digital ini dapat } \\
\text { mendeteksi buah dengan } \\
\text { benar? }\end{array}$ & $\begin{array}{l}(10) \\
30,3 \%\end{array}$ & $\begin{array}{l}(19) \\
57,6 \%\end{array}$ & $\begin{array}{l}(0) \\
0 \%\end{array}$ & $\begin{array}{l}(0) \\
0 \%\end{array}$ & $\begin{array}{c}(4) \\
12,1 \\
\%\end{array}$ & 33 \\
\hline 3 & $\begin{array}{l}\text { Apakah desain tampilan } \\
\text { aplikasi Segmentasi Citra } \\
\text { Digital ini menarik? }\end{array}$ & $\begin{array}{c}(10) \\
30,3 \%\end{array}$ & $\begin{array}{c}(7) \\
21,2 \%\end{array}$ & $\begin{array}{l}(16) \\
48,5 \\
\%\end{array}$ & $\begin{array}{l}(0) \\
0 \%\end{array}$ & $\begin{array}{l}(0) \\
0 \%\end{array}$ & 33 \\
\hline & Apakah fitur dan fungsi & & & (4) & & & \\
\hline 4 & $\begin{array}{l}\text { Aplikasi Segmentasi Citra } \\
\text { Digital ini berjalan dengan } \\
\text { baik? }\end{array}$ & $\begin{array}{c}(7) \\
21,2 \%\end{array}$ & $\begin{array}{c}66,7 \\
\%\end{array}$ & $\begin{array}{c}12,1 \\
\%\end{array}$ & $\begin{array}{l}(0) \\
0 \%\end{array}$ & $\begin{array}{l}(0) \\
0 \%\end{array}$ & 33 \\
\hline 5 & $\begin{array}{l}\text { Apakan aplikass Segmentasi } \\
\text { Citra Digital ini memudahkan } \\
\text { untuk mengenali jenis buah } \\
\text { perkebunan? }\end{array}$ & $\begin{array}{l}(12) \\
36,4 \%\end{array}$ & $\begin{array}{l}(21) \\
63,6 \%\end{array}$ & $\begin{array}{l}(0) \\
0 \%\end{array}$ & $\begin{array}{l}(0) \\
0 \%\end{array}$ & $\begin{array}{l}(0) \\
0 \%\end{array}$ & 33 \\
\hline \multirow{3}{*}{6} & $\begin{array}{l}\text { Apakah aplikasi ini } \\
\text { mempunyai kemampuan dan }\end{array}$ & (10) & (23) & (0) & (0) & (0) & 33 \\
\hline & $\begin{array}{l}\text { fungsi sesuai yang } \\
\text { diharapkan? }\end{array}$ & $30,7 \%$ & $69,2 \%$ & $0 \%$ & $0 \%$ & $0 \%$ & \\
\hline & Rata-rata & $\underset{\substack{29,29 \\
0 / 0}}{2}$ & $58,6 \%$ & $\begin{array}{c}10,1 \\
\%, 6\end{array}$ & $0 \%$ & $\underset{\%}{2,02}$ & $100 \%$ \\
\hline
\end{tabular}

\section{V.CONCLUSIONS AND RECOMMENDATIONS}

Based on the above results, the authors conclude Application Segmentation Digital Image Classification Fruit Plantations In Politani Samarinda making the application of the segmentation of image classification fruits have been getting the results that can recognize the type of fruit based form by using thresholding for image segmentation and Artificial Neural Network (ANN) for classification or grading the image of fruit plantations in POLITANI Samarinda.

The advice in the development of this application is This application can be developed to be more specific and rectify its shortcomings, add and can detect the level of maturity in the image and fruit plantations can be developed on other platforms such as ios, android and windows phone platforms.

\section{REFERENCE}

[1] Aditya B. (2014). "Fruit Recognition System Using Discrete zconsine Transform method and Euclidean Distance". Transient. Vol.3, Nomor.2

[2] Ambarwati A.Rossi P.Sutarno. (2016). "Digital Image Segmentation Using Thresholding Outsu For Comparative Analysis of Edge Detection" .Annual Research Seminar.Vol.21, Nomor.1

[3] Anonymous. (2016) .Selayang POLITANI Pandang. http://politanisamarinda.ac.id (accessed 20 September 2018).

[4] Arinda YPPalma NPRiska H.Ella P.Jumiaty.Putut PW (2017). "Digital Image Segmentation Form Leaves On Plants in Samarinda Politani Method Using thresholding" Information .Jurnal Mulawarman.Vol.12.Nomor.2: 1-3

[5] Crane, R. (1997). A Simplified Approach to Image Processing Classical and Modern Techniques in C. Upper Saddle River: Prentice Hall PTR

[6] Destyningtias B., S. and T. Heranurweni Nurhayati. (2010). The floating Image Segmentation Method. Elektrika Journal. Vol.2, No.1, 2010: 39-49.

[7] Fisher, R .; Perkins, S .; Walker, A .; Wolfart, F. (2003). Roberts Cross Edge detector. [On line]. homepages.inf.edu.ac.uk.rbf / HOPR2 / Roberts.ht m

[8] Gonzalez, RC; Woods, RE (2002) .Digital Image Processing. Prentice Hall.

[9] Hermawan, A., (2006). Neural Networks and Aplikasinya.Yogyakarta: Andi

[10] Kumaseh MRLuther.L.Nelson.N. (2013). "Fish Digital Image Segmentation Method Using Thesholding" Scientific Journal Sains.Vol.13 Nomor.1. 
[11] Kusumadewi, Sri. (2003). "Artificial Intelligence (Techniques and Applications)", Graha Science, Yogjakarta

[12] Lesnussa, YES, S. Latuconsina, ER Persulessy. (2015). " Artificial Neural Network Applications Backpropagation"Jurnal Integrative Mathematics. Volume 11 \# 2

[13] Munir, R. (2004). Digital Image Processing. Informatics. Bandung.

[14] Noor, SC (2011). "Changing Image Color Being Grayscale and Binary Image" Journal of Dynamic Information Technology. Vol.16 Nomor.1

[15] Pahlevi.RN (2018). "Applications Image Processing Pattern Leaf premises method of artificial neural network (ANN)". D4 applied undergraduate thesis informatics management majors: Agricultural Polytechnic State Samarinda, 37-40.a

[16] Pamungkas, A. (2016). Artificial Neural Networks for Classification Citra Leaves. https://pemrogramanmatlab.com (accessed on June 24, 2019).
[17] Prasetyo, E. (2011). Digital Image Processing and Applications Using Matlab. Andi, Yogyakarta.

[18] Purba, D. (2010). Digital Image Processing. Andi, Yogyakarta

[19] Puspitaningrum D., (2006). Introduction to Artificial Neural Networks, Publisher Andi Yogyakarta.

[20] Suhendra, A. (2012). Image Processing Introduction Lecture Notes Http: // ftp. Gunadarma.Ac.Id (downloadable October 2, 2018).

[21] Sutoyo, T., et al. (2009). Theory of Digital Image Processing. Andi Publisher.

[22] Kusumadewi, Sri. (2003). "Artificial Intelligence (Techniques and Applications)", Graha Science, Yogjakarta

[23] Vincent, S, T, S., Edy, M., Dwi, NO, and Wijanarto. (2009). Theory of Digital Image Processing. Yogyakarta: ANDI. 